\title{
INTELLECTUAL PROPERTY IN THE CONTEXT OF THE CONTEMPORARY SOCIETY
}

\author{
Vesna Baltezarevic ${ }^{33}$, Radoslav Baltezarevic ${ }^{34}$, \\ Borivoje Baltezarevic ${ }^{35}$
}

\begin{abstract}
The intellectual creators are, with their creations, bringing comparative advantages to products, contributing to employment, strengthening the economic basis and in the best way representing the state. Intellectual Property, together with other intangible assets, in developed countries accounts for more than half of the total investment. In the modern world, we are completely surrounded by various categories of intellectual property that often exceed the value of the thing in which they are contained, but the problem is that we are either unaware of it, or are ignoring this fact. A particular problem is the economic potential of the country that prevents poor countries to adopt intellectual capital as an essential economic resource, and the lack of will to protect intellectual creators.

In recent decades, because of that, has been opened dilemma whether to change the concept of intellectual property in the sense of intellectual creativity to be equally available both to developed countries and developing countries.
\end{abstract}

KEY WORDS: Intellectual Property, Economic Development, Economic Potential, Intellectual Creators, Dilemma

$$
\begin{aligned}
\text { JEL: D83,P14 } \\
\text { UDC: } 330.34 \\
338.46: 008 \\
347.77 / .78
\end{aligned}
$$

COBISS.SR-ID 227957772

\footnotetext{
${ }^{33}$ Corresponding author,Faculty of Culture and Media, "John Naisbitt" University, Belgrade, Serbia, e-mail: vesnabal@gmail.com

${ }^{34}$ University of the Middle East in Kuwait, e-mail: trilliongarden@yahoo.com

${ }^{35}$ Faculty of Culture and Media, “John Nesbit” University Belgrade, Serbia, e-mail: baltezb@yahoo.co.uk
} 


\section{INTRODUCTION}

Intellectual property is the most profitable area of each country, and its protection, through a system of national and international rules, which are called intellectual property rights, is necessary for the acquisition and financing of innovation and creativity, which in turn, lead to economic, cultural and social progress.

The invention, as a result of spiritual creativity, first appears at the beginning of human civilization. Man, thanks to inventing, turns Stone into the Iron Age, and eventually creates the industrial society. However, although the invention has always been an inseparable element of all human activities, awareness of the social importance of the invention was formed much later (Besarović, 2005, p.33).

Innovation and creativity are gaining in importance when bearing in mind that intellectual property, along with other intangible assets, in developed countries accounts for more than half of the total investment. Increasing labor productivity is not only based on the increase of mass physical labor, but also on the amount of knowledge embedded in a product. This becomes clear when one bears in mind the established scientific fact that the coefficient of productivity of creative work 116 - if the productivity coefficient routine work marked from the 1 .

Intellectual property is a general, legal-technical term for the various creations of the human mind, and commercial symbols, which are intangible assets that can be protected by different types of exclusive rights that are substantially similar to the real rights. They are suitable for commercialization and exploitation in the market.

The concept of intellectual property was adopted at the international level only after the Convention on the establishment of the World Intellectual Property Organization has entered into force, in the seventies of the twentieth century.

Intellectual capital occupies a prominent place in the literature, as a basic resource for providing a competitive advantage to companies, since the intellectual material (knowledge, information, intellectual property, experience) can be used for creating new values and lasting wealth.

Knowledge is treated as personalized wealth, since the use of knowledge leads to highquality base of the economy and society as a whole. Knowledge refers to the ability to collect and apply information, a set of skills and ideas, a set of experiences, data, opinions, intuition and expert insight, or a problem-solving ability.

Accumulation, transmission and management of knowledge have long since become an imperative of economic growth and development. The interest in knowledge management is increasing because it is clear that its impact is crucial for creating competitive advantage (Baltezarevic et al., 2011).

Disposition of the right information at the right time ensures to the company a leading position in the market and creates a sustainable competitive advantage. It also opens the possibility of forming significant databases with the aim of maintaining and increasing market share, and profits. In the modern world, of which we are a part, we are surrounded by numerous achievements of the human intellect. The will and talent without the material basis cannot provide patents that can affect the transformation of the human community. Such material basis is provided due to legal regulations that define conditions for the exploitation of innovation.

In parallel with the globalization process, new fields of economy have been created, which are defined in Western literature as knowledge-based economy, knowledge 
economy, economy based on information and the information economy. The knowledge economy can be seen as a part of the economic system that is associated with the processes of formation, dissemination and use of knowledge, as well as the characteristics of the particular state of the economy, in which knowledge appears as a key determinant of development of its growth and development, and as an economy based on knowledge. Knowledge, information, skills, innovation and revolutionary ideas push the boundaries of social and economic growth and development, becoming a key wealth and production resource (Baltezarević, Baltezarević, 2010).

Knowledge is the most important in the process of creating a competitive advantage, economic growth and development. Knowledge has to be a systematic process that incorporates an understanding of customer needs and business environment and the skills and experience of employees. Investing in technology is desirable because it improves operations and reduces business processes. However, technology alone is not the answer to sharing knowledge - it should only be done with people. . People determine the success of the organization. Each organization is unique - with its own story about the achievements, culture, company reputation, products and people, but they all have to develop close relationships with coworkers and clients. Organizations applying quality communication to employees placed the necessary information from anywhere at any time. The key to acquiring tacit knowledge is experience. Without a common experience, it is very difficult for people to share with each other thinking processes. Employees over time acquire special skills that are based on learning and work experience and apply it in their daily work.

\section{CREATIVITY AS A PREREQUISITE}

The achievements of today's civilized world were created thanks to the creativity, freedom of the human spirit and its creations. Creators bring comparative advantages of products, contributing to employment, strengthening of the economic basis and they are representing the country in the best way. Unfortunately, they are far less esteemed and valued than they deserve.

Creativity is a skill that is practiced and developed like any other. Einstein said: I am not smarter than others, I just think more! (Muk, 2007). Authors who are engaged in the research of creativity often rely on the definition by which creativity is the ability to produce work that is not only new (ie. An original, unexpected), but also useful (ie. Adjusted restrictions imposed by the given task) (Barron, 1995).

Creativity is the ability to create something new through the imagination. Creative people are just people who have a "web of intellectual qualities, personality traits, motivation, emotions and other factors, which in their concentration and focus are the basis for creative achievements." (Karlavaris, Kraguljac, 1981).

Creativity is the power of the creative spirit, the thought process that must start with an idea, while the outcome is its realization. If there is no realization, there is no creativity, as an activity that offers new products in the material or in the spiritual sphere. It is important that these products are genuine, that they are the result of a creative process that lead to successful responses to individual and social needs. 


\section{IN SUPPORT OF THE INTELLECTUAL PROPERTY PROTECTION}

The concept of intellectual property was first mentioned in the judgment of the District Court of the State of Massachusetts from 1845. In legal theory and literature of France, the term propriété intellectuelle, was first used by Alfred Nion (1846). The term "intellectual property" has been widely used since the seventies of the last century, from the moment of entry into force of the Convention establishing the World Intellectual Property Organization (1967). In Section Two of this Convention, definition of intellectual property is given: the term "intellectual property" shall include rights relating to: literary, artistic and scientific works; interpretations of artists and performers and art by performing artists, phonograms and radio broadcasts; inventions in all fields of human endeavor; scientific discoveries; industrial designs; factory, trade and service marks, and trade names; protection from unfair competition, and all other rights resulting from intellectual activity in the industrial, scientific, literary and artistic field. Trade secrets and know-how can also be protected through confidentiality agreements and contracts with employees.

The purpose of the system of intellectual property rights is an incentive for innovators to create new inventions and works. In return, the company receives a steady stream of innovations that drive economic, cultural and social progress. Intellectual property rights are a mechanism that allows innovators, creators and producers to finance their work through the market. There are other models for financing, such as government funding or private patronage, but intellectual property rights remain the most basic and common form of financing used by individuals and organizations for their work and its spread.

Traditional theories of intellectual property are based on two assumptions. One is that information technology can be easily copied, which, in the absence of protection, discourages any incentive to invest in innovation. The second is that the market should be the main mechanism for the exchange of technological information between companies. There are authors who argue that, within the modern systems of intellectual property protection, the significance of the two assumptions is overrated. In most cases copying of the technological information is neither easy nor cheap, so unauthorized copying cannot be simply accomplished and does not represent an attractive option. On the other hand, the costs of appropriation and transfer of technological information through the market are not always the lowest. Some authors argue that further strengthening of property rights in the information technology may be not only unnecessary but, also counterproductive to the overall technological progress (Mandewille, 1996).

Protection of intellectual property also encourages the production and dissemination of knowledge and a wide range of quality products and services. Intellectual property protection contributes to economic growth in both developed and developing countries by encouraging innovation, cultural diversity and technical development as part of a wider political framework. If properly used, intellectual property rights can also be a key asset for the eradication of poverty through trade. Intellectual property is unique and it is the result of personal creativity and innovation. In each case, the intellectual property stimulates progress, transforming society and adding value to our lives. It is because of such great people who have improved the science and provided a better and easier life to humanity; today in the civilized world we are experiencing the increasing protection of the intellectual, moral and economic rights of creators.

But, we have to look at it that developed countries and global companies work together and use copyright to create regional and global monopolies. Western countries use international law, trade agreements and the threat of sanctions to ensure their own position. Other countries are degraded as a source of cheap labor in the production of copyrighted 
and branded goods for the West. The need for cheaper versions of copyrighted goods has led to the creation of markets in Asian countries. What Western companies define as piracy and an attack on their protected rights in developing countries such practices are viewed as an act of economic retaliation against copyright.

\section{THE ECONOMIC APPROACH TO THE PROTECTION OF INTELLECTUAL PROPERTY RIGHTS}

The economic approach to the protection of intellectual property is based on the concept of efficiency. Protection is acceptable while generating benefits to society that exceed the corresponding costs and we cannot talk about its justification in cases where the costs exceed the benefits. Intellectual property protection creates a significant incentive to undertake new research and the creation of new works of art. Without protection, many of these works would never have occurred. Without legal protection, investment in intellectual goods would not be taken. Modern world economy cannot be imagined without investing in the development and exploitation of intellectual property. Businesses must constantly improve their products and services if they want to achieve and maintain market competitiveness.

Any economic activity starts with an idea (intellectual energy), which are then converted into action. Scientists who deal with these issues concluded that the valuation of intellectual property is much more an art than science and a skill.

The costs of creating new ideas often depend on the extent to which innovators can take ideas from others, or to what extent they can continue on the basis of previous contributions. Securing exclusive rights to appropriate intellectual creations, consumers are brought into disadvantaged position, compared to the scenario in which when competition is allowed. This is manifested primarily through major monopolistic price-protected products and limited choice.

Economic theory justifies traditionally strong intellectual property rights and their adequate consistent, referring to the fact that the guaranteed property rights are one of the pillars of modern market economies. Intellectual property, however, has another role, and it is reflected in encouraging creators and innovators to disclose the results of their work. In this way intellectual property rights are becoming a key factor in establishing of the information market.

\section{CONCLUSION}

Protection of intellectual property through the system of national and international rules, which are called the intellectual property rights, is necessary for acquiring and financing of innovation and creativity, which in turn, lead to economic, cultural and social progress. The community has provided intellectual property rights to encourage inventions and creative works, that are beneficial both to the society and an individual, as well as to assist innovators and creators to be able to live from their work. These rights, which can be exercised by individuals or organizations (scientific research or faculty), are recognized by the states all over the world. The system is designed to maintain a balance in achieving the needs of both creators and users. 
But, this is not true in the real life. Global distribution of intellectual property rights is extremely unbalanced. Many countries are caught in a spiral of poverty because they are unable to pay the high fees for obtaining licenses.

Advocating that the law on the protection of intellectual property rights have to be adapted and become more easily available to the poor population encountering fierce resistance of multinational corporations. In any case, the protection of intellectual property rights should exist for the motivation and protection of intellectual creators. But, we believe that it should be found an option for customizing these rights for the application of innovation in developing countries also. Otherwise, we will be faced with the development of piracy that threatens the rights of creators and users also. How to do that? It is still a great dilemma.

\section{REFERENCE}

[1] Baltezarević, V., Paunković, J., Baltezarević, R. (2011). Role of "know- how" in business positioning process in Serbia, Belgrade: Megatrend University, 9th International Scientific Conference Serbia Facing the Challenges of Globalization and Sustainable Development. (p. 129-135).

[2] Baltezarević, V.,Baltezarević, R. (2010). Role of „Intelligent organization“in the company revival process", Forces Driving the Revival of the Companies and Economy, Belgrade: Megatrend. (p. 489-497).

[3] Barron, F. X. (1995). No rootless flower. Ecology of creativity. Hampton:Cresskill,NJ:

[4] Besarović, V. (2005). Intelektualna svojina. Beograd: Centar za publikacije Pravnog fakulteta.

[5] Karlavaris, B.,Kraguljac, Mira. (1981). Razvijanje kreativnosti putem likovnog vaspitanja u osnovnoj školi, Beograd: Prosveta

[6] Convention establishing the World Intellectual Property Organization 1967. http://www.arsetnorma.com/Serbian/inter/Konvencija\%20o\%20osnivanju\%20Svetske $\% 20$ organizacije\%20za\%20intelektualnu\%20svojinu.htm

[7] Mandewille, T. (1996). Undestanding Novelty: Information, Technological Change and the Patent System, Ablex Publishing.

[8] Muk, K. (2007). Kreativnost. http://www.centar-angel.hr/HR/articles/Kreativnost.php

[9] Nion, A. (1846). Droits civils des auteurs, artistes et inventeurs, ou application des dispositions des codes civil, de commerce et de procédure, aux droits attribués par les lois existantes aux auteurs et inventeurs en matière d'art, de science, de littérature et d'industrie: Mémoire qui a remporté la première médaille d'or au concours ouvert en 1844, entre les docteurs, devant la Faculté de droit de Paris. Paris: Joubert. 